Article

\title{
Genes of Gall 200C and Nematode 200C May Develop Biomed- ical Vaccines Against Plants and COVID-19 Diseases: Ad- vanced Medical Science Technology Agriculture Health Issues
}

\author{
Subhas Chandra Datta ${ }^{1,2, *}$
}

How to cite this paper: Datta S.C. (2021). Genes of Gall 200C and Nematode 200C May Develop Biomedical Vaccines Against Plants and COVID-19 Diseases: Advanced Medical Science Technology Agriculture Health Issues . Journal of Biomedical and Life Sciences, 1(1), 22-37. Retrieved from https://www.scipublications.com/journal/index.php/jbls/article/view/73

Received: July 2, 2021

Accepted: August 15, 2021

Published: August 16, 2021

Copyright: (c) 2021 by the authors. Submitted for possible open access publication under the terms and conditions of the Creative Commons Attribution (CC BY) license (http://creativecommons.org/licenses /by/4.0/).

\author{
${ }^{1}$ Department of Zoology, Research Fellow, VisvaBharati, Santiniketan-731235, West Bengal, India. \\ ${ }^{2}$ Headmaster and Secretary, Kanchannagar D. N. Das High School (HS), Kanchannagar, Burdwan Municipality, Purba \\ Bardhaman, Burdwan-713102, West Bengal, India. \\ *Correspondence: dattasubhas@rediffmail.com ; +91-9832192464.
}

\begin{abstract}
The outbreaks and quick spread of severe-acute-respiratory-syndrome-coronavirus 2 (SARS-CoV-2), causing the coronavirus disease 2019 (COVID-19), have badly affected the whole world due to continuous emergence-and-transmission of the latest-new viral-genomes forming new-variants revealing patterns of the SARS-CoV-2 outbreak-and-global-pandemic with badly affecting advanced-medical-science-technology-communication-agriculture-agronomy-plant-breeding-horticulture, health-environment-socio-economy, and different-issues. India's emphasis on okra, the 'Nature's-Gift to Human-Disease-Free-Healthy-Life' and the most 'Economically-ImportantNumber-One-Consumption Vegetable-Crops' is destroyed by various-diseases causing pathogens like the root-knot (RK)-diseases caused by the nematodes, Meloidogyne incognita (Kofoid \& White) Chitwood, and easily checked by many chemical-pesticides. But it causes different carcinogenic effects on the environment and our life. So it is an urgent need to develop potential biomedicines. The pretreatments with ultra-high-diluted-biomedicines (UHDBMs) Gall 200C and Nematode 200C, prepared from okra-root-galls (ORG) and nematode-females (NF) respectively, applied by foliar spray@ $20 \mathrm{ml} /$ plant, are highly effective against the root-knot-disease of okra, Abelmoschus esculentus (L.) Moench Cv. Ankur-40, with the increasing growth of plants and fruits-production. The UHDBMs-Gall 200C is more effective than the Nematode 200C. Both the pretreatments-UHDBMs are responsible for induce-systemic-acquired-defense-response of the pretreated-plants through the expression of pathogenesis-related (PR)-proteins-genes (22-14 numbers), which are more or less similar-molecular-range (295kD-11kD) of many coronavirus, which will be responsible for preventing-RK and COVID-19 like virus-diseases by inducing-defense-resistance or increasing innate-immunity respectively, and advanced in medical-science, technology, communication, agriculture, agronomy, plant breeding, horticulture, health, environment, socio-economy, and different application-issues with pollution-free globe, developing new-preventive typical-biomedical vaccines or

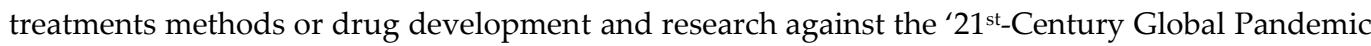
COVID-19 like Any Viral Diseases' which lead to optimal contributions to the field of policymaking drug and vaccine development emphasizing new or important aspects of the study, and synthetic production of UHDBMs will be more practical implications, and social implications in the future research. And the farmers and the world would be benefitted most; by collecting and uprooting gall-roots after harvesting for cost-effective bio-controlling plant-diseases, and profit from shellingand-buying of whole plants, fruits, and gall-roots also, and helps for the benefit of global health by developing the most cost-effective, personalized, non-toxic, easily-preparable, easily-maintainable, easily-available and suppliable, vaccines or treatments methods from their own product.
\end{abstract}

Keywords: Genes; Gall200C-and-Nematode200C; Plants-and-COVID-19-Diseases; Develop; Biomedical-Vaccines; Advanced-Medical-Science-Technology; Agriculture-Health Issues 


\section{Introduction}

\subsection{Causes and Effects of Global Pandemic Problems}

The outbreaks and quick spread of severe acute respiratory syndrome coronavirus 2 (SARS-CoV-2), causing the coronavirus disease 2019 (COVID-19), have badly affected the whole world due to continuous emergence and transmission of the latest new viral genomes forming new variants revealing patterns of the SARS-CoV-2 outbreak and global pandemic with badly affecting advanced in medical, pharmaceutical, science, technology and communication, agriculture, health, agronomy, plant breeding and horticulture, environment, socio-economy, and different issues, and the ancient viral epidemic involving host coronavirus interacting genes more than 20,000 years ago in East Asia [1-20]. The coronavirus attacks different organs, and it causes 'brain fog' and other neurological symptoms through multiple mechanisms, multipronged, attack certain brain cells directly, reduce blood flow to brain tissue, or trigger the production of immune molecules that can harm brain cells, memory loss, strokes, and other effects on the brain [21]. It is reported that the genetic variants have a strong statistical association with a person's chances of developing severe COVID-19, and genome studies have discovered some genetic risk factors for disease [22]. Although it has revealed the importance of severe acute respiratory syndrome coronavirus 2 (SARS-CoV-2) transmission from pre-symptomatic, asymptomatic, and mildly symptomatic (PAMS) cases, the virological basis of their infectiousness remains largely unquantified, and the reasons for the rapid spread of variant lineages of concern, such as B.1.1.7, have yet to be fully determined, and individual and network heterogeneity for a pandemic; in some countries has been the failure to understand, and take account of, the multilayered systemic interdependencies that spread the effects of the pandemic across social, technological, economic and health-care dimensions, and also for viral transmission and evolution dynamics of SARS-CoV-2 in shipboard quarantine [23-26]. A growing share of infections among unvaccinated youths in many countries due to an ever-increasing proportion of new infections is in younger age groups [27].

India emphasis on the most important and crucial aspect of sustainable development in the agricultural sector and the backbone of the economy, cultivating the okra for the food security which is but badly impact of the COVID-19 pandemic on food security, agriculture, massive consequences on health and livelihoods of developing countries [28], and it not only reduced incomes but also disturbed supply chains, chronic and acute hunger, due to various factors like conflict, socio-economic conditions, natural hazards, climate change, and pests like the locust outbreaks, etc. forming this crisis of different 23 countries with the other zoonotic diseases remain a recurrent threat [29]. And it is well known that the okra is one the most economically important, commercially exploited, number one consumption in a variety of ways vegetable crops [30], which is the oldest widely cultivated oligo purpose, significantly contribute for nutritional, medicinal and industrial application [31], and used as traditional medicine, achieving the 'Nature's Gift to human disease-free healthy life' multipurpose crop [15,19,20,32-34], achieving India first in the world for the fruits rich in vitamins, calcium, folic acid, carbohydrates, phosphorus, magnesium and potassium, iodine, mineral matters, and a good source of superior nutritional quality for human nutrition for preventing different diseases; like cardiovascular disease, type 2 diabetes, kidney diseases, skin infection, digestive diseases, some cancers, antioxidant, nootropic, eye, body immunity, blood pressure, obesity, asthma, constipation, heart disease, sexual health, and neurological disorders, etc., and mature fruit and stems contain crude fiber, used in the paper industry and sugarcane industry [32-35]. The enrich source of nutrients, minerals, and fibers of okra has invited too many pathogens, pests, and diseases infestation [36], and only the nematode pathogens causing root-knot, damage $10-40 \%$ of the total crop production annually, causing serious problems in our country and this indirectly affects our advanced agronomy, plant breeding, horticulture, environment, socio-economy, green-science, technology, communication, issues, 
and agricultural-economy also. Though the pesticides are very much potential. But it creates several problems in toxicity, pollution, cost-effectiveness, environment-friendliness, and biodiversity conservation [3-20,32]. On the other hand, the pesticides block functional first known gene transfer between plants to insects or animals, which is used in the host's defenses mechanism for new pest-control strategies also [37], and recently in the 31countries of the globe that higher airborne pollen concentrations correlated with increased SARS-CoV-2 infection rates [38].

Recently after long lockdowns in Purba Bardhaman, West Bengal, India (Figure 1), only two days (12-13 th July 2021) show that the total COVID-19 positive cases are 3749437524 , the total number of discharge cases are 38057-38103, the total number of COVID19 death is $443-444$, rate of recovery is $97.42 \%-97.56 \%$ respectively, and rate of mortality is same $(1.16 \%)$. So, it is an urgent need to find out by developing policy-initiative, cheap, non-phytotoxic, and non-pollutant potential-high-diluted-biomedicines for preventing both the pandemic crisis by improving the agriculture system with the findings and other new research to develop future support and treatments.

\subsection{Previous Study}

It is already seen that the many; pure compounds, homeopathy, allelopathy, plant extracts, phytomedicine, bio-agents, intercropped- or multi- cropped biomedicines, biomedicinal meals, biomedicine-vaccine, social-vaccine, policy-developed global-vaccine, many models, etc. are applied to regulate against different diseases causing pathogens, control the plants- and animal- diseases causing pathogen [3-20,32,39-66]. But it's not achieving significant success in all the cases because of different problems.

\subsection{Primary Observations}

It has also been primarily observed that the animals- and plants -high or ultra-highdiluted biomedicines; Nematode Extract (NE) or nematode MT (NMT) and root galls (RG) extract or Gall MT is the safe alternative method for preventing root-knot diseases caused by nematode pathogens, by inducing their natural defense response of the host plants [1520,39-42,44], and it may control or prevent the novel SARS-CoV-2 variant, the delta plus variant which is likely similar to that of the preexisting delta variant of 10 countries [67].

\subsection{Aims and Objectives}

The aims and objectives of the recent experiment to confirmative use the systematic signaling and induced natural defense or immunity in the host plants by applying ultrahigh-diluted biomedicines; Gall 200C and Nematode 200C, prepared from; gall roots (GR), and Nematode Females (NF) respectively, as a preventive measure against root-knot of okra plants (OP), and COVID-19 diseases ideas, and also to find out the actual reasons of the genetic effects on the ultra-high-diluted-biomedicines for preventing diseases.

\subsection{Main Contribution of the experiment}

The recent study contributes to the sustainable development of the most policy-initiative, cheap, non-toxic, pollutant-free, and side-effect free potential-high-diluted-biomedicines global vaccines; Gall 200C and Nematode 200C, for controlling both the pandemics; root-knot diseases, and the future pandemic COVID-19 like virus diseases also, by enriching agriculture, environment-health-socio-economy-medical-pharmaceutical-science-technology-communication-issues, and the findings of new research in drug development for the future support and the best treatments or potential vaccine for whole worlds. 


\section{Daily Press Briefing \\ PurbaBardhaman \\ Date: 13:07/2021 (Tp to 5.00 PMI)
(Keport to by yed by 7.00 PM Delly) \\ Part -I: Related to COVID-19}

\begin{tabular}{|c|c|c|}
\hline i) & $\begin{array}{l}\text { Total No. of COVID Positive Patients found ou the } \\
\text { day of reporting * }\end{array}$ & 46 \\
\hline ii) & Total no of COVID positive patients"* & 38103 \\
\hline ii) & Total no of active patients as on today"* & 485 \\
\hline iv) & Total no of discharged cases & 37174 \\
\hline v) & Total no of COVID death recorded & 44 \\
\hline \multicolumn{3}{|c|}{ - Quarantine status: } \\
\hline vi) & Total no of persons under instinutional quarantine & 0 \\
\hline vii) & Total no of persons under housse quarantine & 0 \\
\hline viii) & $\begin{array}{l}\text { Total no of persons under quarantine froom } \\
\text { Maharashra, Delhi, Gujurat, Tamil Nadu \& M.P. }\end{array}$ & 0 \\
\hline ii) & $\begin{array}{l}\text { Total no of persons under quarantine from other state } \\
\text { of India }\end{array}$ & 0 \\
\hline s) & $\begin{array}{l}\text { Total no of persons relased from institutional } \\
\text { quarantine }\end{array}$ & 0 \\
\hline \multicolumn{3}{|c|}{ - Testing status: } \\
\hline $\mathrm{xi})$ & \begin{tabular}{|l|l|} 
Total no of Sample collected up to 12.07 .2021 \\
\end{tabular} & 287599 \\
\hline sii) & Toal no of Sample tested & 286937 \\
\hline siii) & Tonal no of Positive cases & 15001 (+53 repeat $+\mathrm{re})$ \\
\hline siv) & Toul no of negative Cases & 270691 (+1192 :pillageirejected) \\
\hline \multicolumn{3}{|c|}{ - Containment Zone status: } \\
\hline sw) & \begin{tabular}{|l|l|l|l} 
Toal no of Containment Zooe as on today \\
\end{tabular} & \\
\hline svi) & \begin{tabular}{|l|l|} 
Toal no of containment withdrawn \\
\end{tabular} & \\
\hline \multicolumn{3}{|c|}{ - Amalysis of Positive Persons Details: On date - Positive- } \\
\hline svili) & $\begin{array}{l}\text { Total No. of Migrant (Other State + Other Dist of } \\
\text { WB): }\end{array}$ & $\infty 0$ \\
\hline sviii) & No. of Persoas in Safé House: & 07 \\
\hline six) & No. of Person in Covid Hospital: & 04 \\
\hline $\mathrm{sx})$ & No. of Persons in Home Isolations: & 42 \\
\hline \multicolumn{3}{|c|}{ Analysis on COVD-19+VeCases: } \\
\hline $\mathrm{ssi})$ & Rate of Recovery* (Percentage) & 97.56 \\
\hline sxiil) & Rate of Mortality" (Percentage) & 1.16 \\
\hline
\end{tabular}

\begin{tabular}{|c|l|l|}
\hline \multicolumn{2}{|l|}{ Keport on Sample Testing: } \\
\hline sxili) & Anrigen Test & 1421 \\
\hline sxiv) & RT-PCR Test & 638 \\
\hline xiv) & Test Result within 24 Hrs. & 1529 (RAT-1421+KTPCR.106) \\
\hline
\end{tabular}

Part- II:

Distribution of COVID Positive Cases found on 13:07/2021

\begin{tabular}{|c|c|c|c|c|c|c|c|c|c|}
\hline $\begin{array}{c}\text { Aushgram- } \\
1\end{array}$ & 。 & Gotsill & 2 & Ketugram-1 & 0 & Mongoikote & 2 & $\begin{array}{c}\text { Burdwan } \\
\text { Municipstity }\end{array}$ & 6 \\
\hline $\begin{array}{c}\text { Aushgram- } \\
\text { \|" }\end{array}$ & 。 & Jamalpur & 4 & Ketugram-11 & 。 & Purbasthati-1 & 4 & $\begin{array}{c}\text { Doinnst } \\
\text { Municipstity }\end{array}$ & 1 \\
\hline Bhatar & 0 & $k \sin \theta-1$ & 。 & Khandoghosh & 2 & Purbasthali-1I & 3 & $\begin{array}{c}\text { Gusksars } \\
\text { Municipstity }\end{array}$ & $\circ$ \\
\hline Burowan-1 & 4 & Koing-1I & 2 & Manteswar & 。 & Raina-1 & 1 & $\begin{array}{c}\text { Ksins } \\
\text { Municipolity }\end{array}$ & $\circ$ \\
\hline Burdwan-11 & 4 & Katwa-1 & 0 & Memari-1 & 4 & Roina-11 & 3 & $\begin{array}{c}\text { Katws } \\
\text { Municipsity }\end{array}$ & 1 \\
\hline Galsi-1 & 2 & Katwa-ll & 1 & Memari-II & 。 & other District & 1 & $\begin{array}{c}\text { Memari } \\
\text { Municipselity }\end{array}$ & $\circ$ \\
\hline
\end{tabular}

\begin{tabular}{|c|c|c|c|}
\hline \multicolumn{2}{|c|}{$\begin{array}{c}\text { Analysis on COVID +Ve Cases on } \\
13 / 07 / 2021\end{array}$} & \multirow{2}{*}{$\begin{array}{c}\text {-Covid Positive } \\
\text { as ou today } \\
04\end{array}$} & \multirow{2}{*}{$\begin{array}{c}\text {-Total Posiáve Cases } \\
2713\end{array}$} \\
\hline & Symptomatic & & \\
\hline 1 1)pe & Asymptomstic & 42 & 39390 \\
\hline & Total & 46 & 38103 \\
\hline \multirow{4}{*}{$\begin{array}{l}\text { Contact } \\
\text { Analysis }\end{array}$} & Primury Counact & 01 & 1519 \\
\hline & Travol from High Burdon Diat of W.B. & $\infty$ & 217 \\
\hline & Trrol from Other Sats & $\infty$ & 435 \\
\hline & No Tranvl History & 45 & 39932 \\
\hline & Total & 46 & 38103 \\
\hline
\end{tabular}

\section{Daily Press Briefing \\ PurbaBardhaman \\ Date: 122072021 (Tp to 5.00 PM) \\ Part -I: Related to COVID-19}

\begin{tabular}{|c|c|c|}
\hline 1) & $\begin{array}{l}\text { Total No. of COVD Positive Patients found on the } \\
\text { day of reporting * }\end{array}$ & 20 \\
\hline ii) & Total no of COVID positive patients"* & 38057 \\
\hline ii) & Total no of active patients as on today"* & 537 \\
\hline iv) & Toal no of discharged cases & 37077 \\
\hline v) & Total no of COVDD denth recorded & 443 \\
\hline \multicolumn{3}{|c|}{ - Quarantime status: } \\
\hline vi) & Total no of persons under instivutional quarantine & 0 \\
\hline vii) & Total no of persons under bouse quarantine & 0 \\
\hline viil) & $\begin{array}{l}\text { Total no of persons umder cuarantine from } \\
\text { Mahnrashra, Delhi, Gujsart, Tamil Nadu \& MP. }\end{array}$ & 0 \\
\hline ix) & $\begin{array}{l}\text { Total no of persons under quarantine from other state } \\
\text { of India }\end{array}$ & 0 \\
\hline x) & $\begin{array}{l}\text { Toeal no of persons relased from institutional } \\
\text { quarantine }\end{array}$ & 0 \\
\hline \multicolumn{3}{|c|}{ - Testing status: } \\
\hline sil & Total no of Sample collected up to 11.07 .2021 & 286829 \\
\hline sii) & Total no of Sample tested & 286209 \\
\hline siii) & Toul no of Positive cases & 14995 (+53 repeat $+v e)$ \\
\hline siv) & Toal no of negative Cases & 270059 (+1192 spillageirejected) \\
\hline \multicolumn{3}{|c|}{ - Containment Zone status: } \\
\hline wi) & Total no of Containment $Z$ Oone as on todxy & \\
\hline svi) & Toal no of containwent withdrawn & \\
\hline \multicolumn{3}{|c|}{ - Amalysis of Positive Persons Details : On date - Positive- } \\
\hline svii) & $\begin{array}{l}\text { Totol No. of Migrant (Other State + Other Dist. of } \\
\text { wB): }\end{array}$ & 00 \\
\hline sviii) & No. of Persons in Safe Houte: & 07 \\
\hline six) & No. of Person in Covid Hospital: & 03 \\
\hline sx) & No. of Persons in Home Isolations: & 17 \\
\hline \multicolumn{3}{|c|}{ Amalysis on COVID-19 +VeCases: } \\
\hline$\overline{\mathrm{xxi})}$ & Rate of Recovery" (Percentage) & 97.42 \\
\hline sxii) & Rase of Mortality" (Percentage) & 1.16 \\
\hline
\end{tabular}

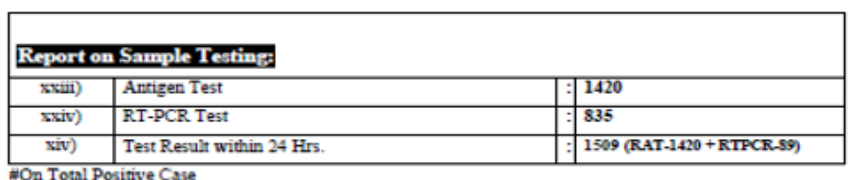

HOn Total Positive Cane

Part- II:

Distribution of COVID Positive Cases found on 12/07/2021

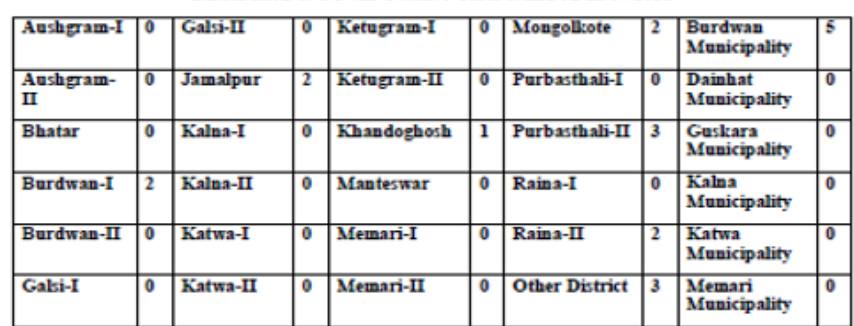

\begin{tabular}{|c|c|c|c|}
\hline \multicolumn{2}{|c|}{$\begin{array}{c}\text { Analysis on COVID + Ve Cases on } \\
12 / 07 / 2021\end{array}$} & \multirow{2}{*}{$\begin{array}{c}\begin{array}{c}\text {-COVID Positive } \\
\text { as out today }\end{array} \\
03 \\
\end{array}$} & \multirow{2}{*}{$\begin{array}{c}\text { "Total Posiave Cases } \\
2709\end{array}$} \\
\hline & Symptomatic & & \\
\hline 1ype & Asymptomatic & 17 & 35348 \\
\hline \multicolumn{2}{|r|}{ Total } & 20 & 38057 \\
\hline \multirow{4}{*}{$\begin{array}{l}\text { Contact } \\
\text { Analysis }\end{array}$} & Primary Counact & $\infty$ & 1518 \\
\hline & Travol from High Burdon Dist of W.B. & $\infty$ & 217 \\
\hline & \begin{tabular}{|l} 
Travol from Other State \\
\end{tabular} & $\infty$ & 435 \\
\hline & No Tranvl History & 20 & 39857 \\
\hline & Total & 20 & 35057 \\
\hline
\end{tabular}

Figure 1. (Part-I\&II). Daily Press Briefing of the Purba Bardhaman District (Date:13/07/2021, Up to 5.00 P.M. Daily). 


\section{Materials and Methods}

\subsection{Place and preparation of high-diluted biomedicines GMT and NMT}

The high-diluted biomedicines Gall MT (GMT) and Nematode MT (NMT), prepared from the root galls (RG) and nematode females (NF) of okra plants respectively which were collected from root-knot (RK) infected roots of the okra plants, Abelmoschus esculentus (L.) Moench Cv. Ankur-40, grown in the experimental garden of the Department of Zoology, VisvaBharati University, Santiniketan - 731235, and they were washed with sterile tap water, homogenizer and extracted with $90 \%$ ethanol at room temperature $\left(25 \pm 2{ }^{\circ} \mathrm{C}\right)$ for 15 days and centrifuged at @3500 rpm for 5 minutes, and then the gall extract (GE) and nematode extract (NE) supernatant was collected respectively and allowed to evaporate at room temperature $\left(25 \pm 2^{\circ} \mathrm{C}\right)$ and both the biomedicines residues were kept over anhydrous calcium chloride $\left(\mathrm{CaCl}_{2}\right)$ for dehydration and stored at $4^{\circ} \mathrm{C}$. The crud GE- and NEbiomedicines residues were mixed with sterile distilled water respectively just before application on the test plants. Both the crude residues were diluted in $90 \%$ ethanol at $1 \mathrm{mg} / \mathrm{ml}$ concentration respectively and were prepared high-diluted biomedicines, Gall MT, and Nematode MT (Original Solution or Crude Extract i.e. Mother Tincture) [4,7,8,11-20,3946,51-66].

\subsection{Ultra-high-diluted-biomedicines Gall 200C and Nematode 200C preparation}

For the preparation of ultra-high-diluted-biomedicines liquid drugs, the high-diluted GMT and NMT were diluted with 90\% ethanol (1:100) proportionate in a round vial respectively which were filled up to two-thirds of its space, tightly crocked, and the vials were given 10 powerful downward strokes of the arm for mechanical agitation (succession), forming the 1st centesimal potency named Gall 1C and Nematode 1C respectively. All the subsequent potencies were prepared by further diluting each potency with $90 \%$ ethanol in the same proportion (1:100) and the mixture was given 10 powerful downward strokes. In this way, different potencies of both the drugs; Gall 200C and Nematode 200C, were prepared respectively [4,7,8,11-20,39-46,51-66].

\subsection{Ultra-high-diluted biomedicines Gall 200C and Nematode 200C-test solutions preparation}

For the preparation of both the ultra-high-diluted test-solution of the biomedicines; Gall 200C, and Nematode 200C, were diluted (v/v) @ 1ml drug/20ml sterile distilled water (in the proportion of drug: water=1:20, containing $0.2 \mathrm{mg}$ drug) respectively, and the highdiluted-biomedicines liquid control-solution of both the drugs were diluted (v/v)@ $1 \mathrm{ml}$ $90 \%$ ethanol $/ 20 \mathrm{ml}$ sterile distilled water (in the proportion of drug: water=1:20) respectively, and the control solution was prepared for comparison to the preparation of test solutions and stored at 4oC for treatments media [4,7,8,11-20,39-46,51-66].

\subsection{Pot Test and Inoculation}

Aseptically germinated seeds of Abelmoschus esculentus (L.) Moench Cv. Ankur-40 was sown at the rate of one seed/pot (32 cm diam.) containing a mixture of clay soil and composted manure $(2: 1 \mathrm{v} / \mathrm{v})$. The soil-filled pots were treated with boiling water 5 (five) times. The pots were divided into four batches/groups; each numbering 10: (i) uninoculated untreated, (ii) inoculated untreated, (iii) pretreatment-Gall 200C inoculated, and (iv) pretreatment-Nematode $200 \mathrm{C}$ inoculated. All the pretreatments were done by foliar spray. The experiment was conducted outdoors at an ambient atmospheric temperature $\left(27 \pm 2^{\circ} \mathrm{C}\right)$ and relative humidity $(75 \pm 5 \%)$. Plants were inoculated at the 12-leaf stage (Day-25) with M. incognita (J2) @ 3425 \pm 75 J2-larvae/plant [4,7,8,11-20,39-46,51-66].

\subsection{Treatments with ultra-high-diluted biomedicines Gall 200C and Nematode 200C- test solutions}

The ultra-high-diluted-biomedicines; Gall 200C, and Nematode 200C -test solutions, were applied respectively into the okra plants and sprayed on plants@20 $\mathrm{ml} /$ treated plants 
three days before inoculation for pretreatments with nematodes-J2 respectively. Control okra plants were treated with an equal amount $(20 \mathrm{ml})$ of control solutions prepared with sterile distilled water, and the plants were regularly watered in the morning and evening. During spraying, the soil surface underneath each plant was covered with a polythene sheet. Plants in both uninoculated untreated and inoculated untreated groups received a spray of an equal amount of control solutions. All treatments were done hygienically. All the data were analyzed by ANOVA (Analysis of Variance). The experiment was repeated thrice. Data from the last experiment are reported here [4,7,8,11-20,39-46,51-66].

\subsection{Densitometer scanning of ORP, OGP, and NF-proteins}

The OR, ORG, and NF-proteins separation were carried out by the method of Laemmli (1970) with the modifications as suggested by the LKB Instructional Manual (1986). A 10\% separating gel and 5\% stacking gel were used. The bands were scanned with a recording electrophoretic scanner (Biomidi, 96-300 densitometers). In Figure 2 and Table 2 , the observation was recorded from the densitometer curve

\subsection{Toxicity Test}

Biomedicines; Gall 200C and Nematode 200C, has exposed directly for the study of toxic effect on nematode juveniles after 2 hours exposure periods at room temperature $\left(20 \pm 2^{\circ} \mathrm{C}\right)$ respectively $[4,7,8,11-20,39-46,51-66,68-71]$.
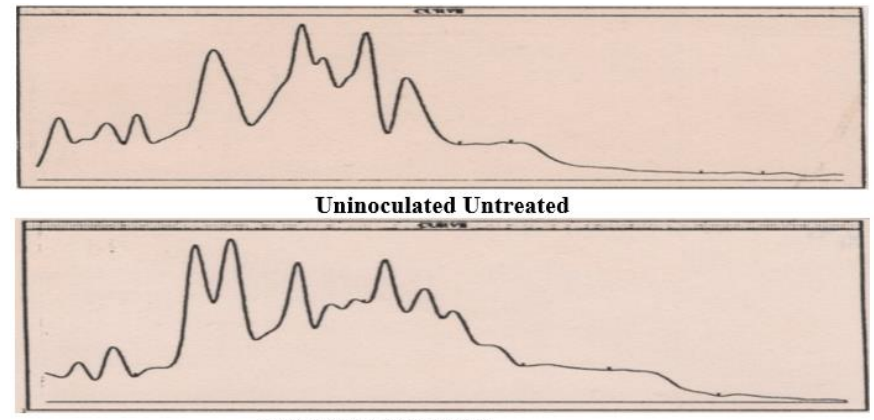

Inoculated Untreated

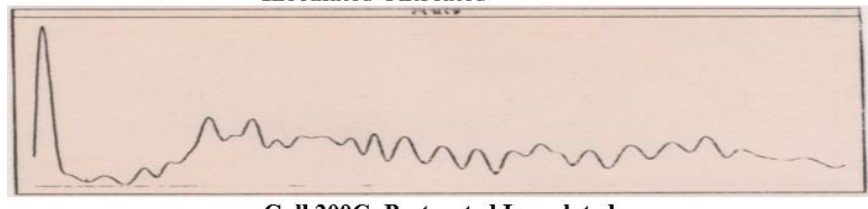

Gall 200C- Pretreated Inoculated

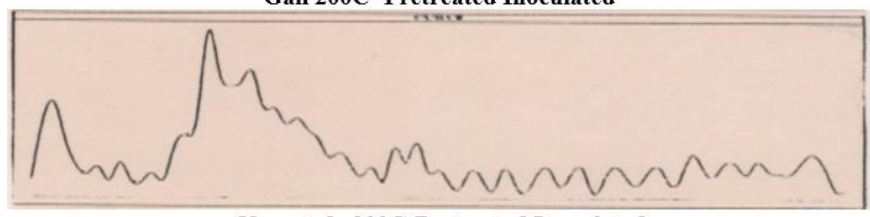

Nematode 200C-Pretreated Inoculated

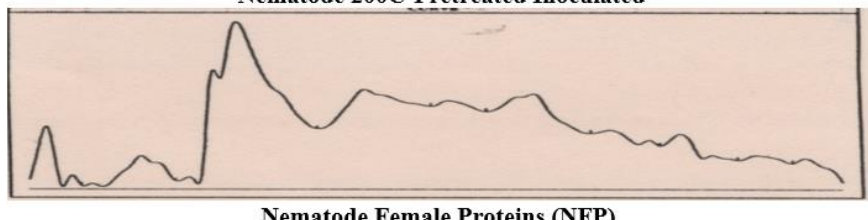

Nematode Female Proteins (NFP)

Figure2. Densitometry tracings of root proteins of the pretreated Gall 200C and Nematode 200C on okra with nematode proteins resolved on poly acrylamide gel electrophoresis (SDS-PAGE).

\subsection{Harvesting}

All the okra plants were uprooted 53 days after the sowing of seeds. The following measure measurement was taken: biomass of shoot, root, and fruits, root gall number, nematode population in roots $(2 \mathrm{~g})$ and soil $(200 \mathrm{~g})$, the protein content of root and fruits. Proteins were estimated by the Folin-phenol method $[68,69]$. All the data were analyzed 
by analysis of variance (ANOVA). The experiment was repeated five times with similar results and the data from the third experiment were represented in Table 1.

Table1. Pretreatment effect of the Gall 200C and Nematode 200C on okra plants ${ }^{\mathrm{x}}$ inoculated with root knot nematodes

\begin{tabular}{|c|c|c|c|c|c|c|c|c|c|c|c|}
\hline \multirow[t]{3}{*}{ Pretreatments ${ }^{Y}$} & \multicolumn{3}{|c|}{ Fresh Biomass $(\mathrm{g})^{\mathrm{X}}$} & \multirow{3}{*}{$\begin{array}{c}\text { Number } \\
\text { of } \\
\text { Fruits }^{x}\end{array}$} & \multirow{3}{*}{$\begin{array}{l}\text { Num- } \\
\text { ber of } \\
\text { Root } \\
\text { Galls }\end{array}$} & \multicolumn{2}{|c|}{$\begin{array}{c}\text { Nematode } \\
\text { Population }^{\mathrm{x}}\end{array}$} & \multicolumn{2}{|c|}{$\begin{array}{c}\text { Protein }^{x} \text { Con- } \\
\text { tent }(\%)\end{array}$} & \multicolumn{2}{|c|}{$\begin{array}{l}\text { Number of } \\
\text { Root Protein }\end{array}$} \\
\hline & \multirow[t]{2}{*}{ Shoot } & \multirow[t]{2}{*}{ Root } & \multirow[t]{2}{*}{ Fruits } & & & \multirow[t]{2}{*}{$\begin{array}{l}\text { Root } \\
(2 \mathrm{~g})\end{array}$} & \multirow[t]{2}{*}{$\begin{array}{l}\text { Soil } \\
(200 \mathrm{~g})\end{array}$} & \multirow[t]{2}{*}{ Root } & \multirow[t]{2}{*}{ Fruits } & & \\
\hline & & & & & & & & & & $\begin{array}{l}\text { Total } \\
\text { Pro- } \\
\text { tein }\end{array}$ & $\begin{array}{l}\text { PR- } \\
\text { Pro- } \\
\text { tein }\end{array}$ \\
\hline $\begin{array}{l}\text { I. Uninoculated } \\
\text { Untreated }\end{array}$ & $\begin{array}{c}199.08 \mathrm{a} \\
{ } \pm 2.08\end{array}$ & $\begin{array}{c}25.23 \mathrm{c} \\
\pm 1.01\end{array}$ & $\begin{array}{c}31.97 \mathrm{a} \\
\pm 1.01\end{array}$ & $\begin{array}{c}20.02 \mathrm{a} \\
\pm 1.04\end{array}$ & 00 & & & $\begin{array}{l}1.08 \mathrm{c} \\
\pm 0.02\end{array}$ & $\begin{array}{l}2.28 \mathrm{a} \\
\pm 0.02\end{array}$ & 11 & 4 \\
\hline $\begin{array}{l}\text { II. Inoculated } \\
\text { Untreated }\end{array}$ & $\begin{array}{l}89.78 \mathrm{c} \\
\pm 1.06\end{array}$ & $\begin{array}{c}68.85 \mathrm{a} \\
\pm 1.43\end{array}$ & $\begin{array}{c}14.01 \mathrm{c} \\
\pm 1.03\end{array}$ & $\begin{array}{l}05.99 \mathrm{c} \\
\pm 1.03\end{array}$ & $\begin{array}{c}386.97 a \\
\pm 96.11\end{array}$ & $\begin{array}{l}903 a \\
\pm 21\end{array}$ & $\begin{array}{l}17 \mathrm{a} \\
\pm 3\end{array}$ & $\begin{array}{l}2.78 \mathrm{a} \\
\pm 0.04\end{array}$ & $\begin{array}{l}1.09 \mathrm{c} \\
\pm 0.01\end{array}$ & 15 & 14 \\
\hline $\begin{array}{l}\text { III. Gall 200C } \\
\text { Inoculated }\end{array}$ & $\begin{array}{c}195.79 \mathrm{a} \\
\pm 1.01\end{array}$ & $\begin{array}{l}29.10 \mathrm{c} \\
\pm 1.02\end{array}$ & $\begin{array}{c}30.78 \mathrm{a} \\
\pm 1.04\end{array}$ & $\begin{array}{c}19.02 \mathrm{a} \\
\pm 1.02\end{array}$ & $\begin{array}{l}14.21 \mathrm{c} \\
\pm 1.33\end{array}$ & $\begin{array}{l}18 \mathrm{c} \\
\pm 18\end{array}$ & $\begin{array}{c}65 \mathrm{~b} \\
\pm 2\end{array}$ & $\begin{array}{l}1.24 \mathrm{c} \\
\pm 0.02\end{array}$ & $\begin{array}{l}2.20 \mathrm{a} \\
\pm 0.02\end{array}$ & 23 & 22 \\
\hline $\begin{array}{l}\text { IV. Nematode } \\
\text { 200C Inoculated }\end{array}$ & $\begin{array}{c}188.44 \mathrm{~b} \\
\pm 2.02\end{array}$ & $\begin{array}{c}33.51 \mathrm{~b} \\
\pm 1.09\end{array}$ & $\begin{array}{c}25.89 \mathrm{~b} \\
\pm 1.01\end{array}$ & $\begin{array}{c}14.06 \mathrm{~b} \\
\pm 1.02\end{array}$ & $\begin{array}{l}45.34 \mathrm{~b} \\
\pm 4.02\end{array}$ & $\begin{array}{l}47 \mathrm{~b} \\
\pm 13\end{array}$ & $76 \mathrm{c} \pm 2$ & $\begin{array}{l}1.48 \mathrm{~b} \\
\pm 0.02\end{array}$ & $\begin{array}{l}1.96 \mathrm{~b} \\
\pm 0.02\end{array}$ & 24 & 19 \\
\hline
\end{tabular}

' $\mathrm{X}^{\prime}$-Mean of 10 replicates with S.E.

' $\mathrm{Y}^{\prime}$-Okra plants inoculated at 12-leaf stage (Day-25) with M. incognita juveniles (3425 $\pm 75 \mathrm{~J} 2 /$ pot), pretreated at 8-leaf stage (Day-22), and harvested 53 days after sowing of germinated seeds.

' $\mathrm{Z}$ '-Means carrying same letters in a column are not significantly different $(\mathrm{P} \leq 0.05)$ by analysis of variance.

\subsection{In Advanced Medical-Science-Technology-Agriculture-Health-Issues}

The many academicians, clinicians, scholars, researchers, scientists, students, farmers, administrators, institutions, communities, associations, teachers, staff, regulators, photographers, visitors, healthcare, media personnel, NGO-Burdwan Green Haunter and Students' Goal, and many effective social clubs, and social organizations, organize street cornering, workshops, seminars, agriculture fair, health camp, campaign, aware, make the news, and publish in different journals emphasis on "Genes of Gall 200C and Nematode 200C May Develop Biomedical Vaccines Against Plants and COVID-19 Diseases: Advanced Medical-Science-Technology-Agriculture- Health-Issues" [3-20,39-66,71].

\section{Results}

\subsection{On Root-Knot (RK) Diseases}

The pretreatment with ultra-high-diluted-biomedicines; Gall 200C, and Nematode $200 \mathrm{C}$ significantly ( $\mathrm{P} \leq 0.05$ by ANOVA) increased plant growth in terms of the fresh biomass of shoot and fruits compared to the inoculated and untreated plants (Table 1). Root galls, nematode population in the root and soil, and root protein content were significantly $(\mathrm{P} \leq 0.05$ by ANOVA) reduced in pretreated plants as compared to the untreated ones (Table 1). The number of fruits and protein content in green fruit was significantly reduced in inoculated untreated plants as compared to the uninoculated ones, and both the pretreatments with biomedicines; Gall 200C, and Nematode 200C showed better plant growth and lesser intensity of the root-knot disease, and Gall 200C showed the best results in all respect (Table 1).

\subsection{On Toxicity}


Both the ultra-high-diluted-biomedicines biomedicines; Gall 200C, and Nematode 200C had not produced any direct toxic effect on nematode because no mortality occurs after 2 hours exposure period.

Table 2. Pretreatment genetic effects of the Gall 200C and Nematode 200C on okra root proteins (ORP) with nematode proteins

\begin{tabular}{|c|c|c|c|c|c|c|c|c|c|c|c|c|c|c|c|c|c|c|c|c|c|c|c|c|c|c|c|}
\hline \multirow{3}{*}{$\begin{array}{c}\text { Pretreatment } \\
\text { Groups } \\
\text { (Except NP) }\end{array}$} & \multirow{3}{*}{$\begin{array}{l}\text { Total } \\
\text { num- } \\
\text { ber } \\
\text { of pro- } \\
\text { teins }\end{array}$} & \multicolumn{25}{|c|}{ Molecular weight $(\mathrm{kD})$ of pretreatment groups } & \multirow{3}{*}{$\begin{array}{c}\text { Total } \\
\text { num- } \\
\text { ber of } \\
\text { PR- } \\
\text { pro- } \\
\text { teins }\end{array}$} \\
\hline & & \multicolumn{25}{|c|}{ Serial number of proteins } & \\
\hline & & 1 & 2 & 3 & 4 & 5 & 6 & 7 & 8 & 9 & $\begin{array}{l}1 \\
0\end{array}$ & 1 & $\begin{array}{l}1 \\
2\end{array}$ & 1 & $\begin{array}{l}1 \\
4\end{array}$ & $\begin{array}{l}1 \\
5\end{array}$ & 1 & 7 & $\varepsilon$ & & & $\begin{array}{l}2 \\
0 \\
\end{array}$ & $\begin{array}{l}2 \\
1\end{array}$ & $\begin{array}{l}2 \\
2\end{array}$ & $\begin{array}{l}2 \\
3 \\
\end{array}$ & $\begin{array}{l}2 \\
4\end{array}$ & \\
\hline $\begin{array}{l}\text { Uninoculated } \\
\text { Untreated }\end{array}$ & 11 & $\begin{array}{l}2 \\
8 \\
0\end{array}$ & $\begin{array}{l}6 \\
0\end{array}$ & $\begin{array}{l}2 \\
4 \\
0\end{array}$ & $\begin{array}{l}2 \\
1 \\
0\end{array}$ & $\begin{array}{l}1 \\
5 \\
5\end{array}$ & 5 & 0 & 5 & $\begin{array}{l}7 \\
0\end{array}$ & $\begin{array}{l}4 \\
5\end{array}$ & 3 & - & - & - & - & - & - & - & . & & - & - & - & - & - & 4 \\
\hline $\begin{array}{l}\text { Inoculated } \\
\text { Untreated }\end{array}$ & 15 & $\begin{array}{l}2 \\
7 \\
0\end{array}$ & $\begin{array}{l}2 \\
4 \\
0\end{array}$ & $\begin{array}{l}2 \\
0 \\
0\end{array}$ & $\begin{array}{l}1 \\
7 \\
0\end{array}$ & $\begin{array}{l}1 \\
4 \\
5\end{array}$ & $\begin{array}{l}8 \\
8\end{array}$ & 8 & 0 & $\begin{array}{l}7 \\
7\end{array}$ & 5 & 8 & 6 & 7 & $\begin{array}{l}2 \\
7\end{array}$ & $\begin{array}{l}1 \\
7\end{array}$ & - & - & - & rata & & - & - & - & - & - & 14 \\
\hline $\begin{array}{l}\text { Gall 200C In- } \\
\text { oculated }\end{array}$ & 23 & $\begin{array}{l}2 \\
9 \\
5\end{array}$ & $\begin{array}{l}2 \\
3 \\
5\end{array}$ & $\begin{array}{l}2 \\
2 \\
0\end{array}$ & $\begin{array}{l}1 \\
8 \\
0\end{array}$ & $\begin{array}{l}1 \\
6 \\
0\end{array}$ & $\begin{array}{l}1 \\
4 \\
0\end{array}$ & $\begin{array}{l}1 \\
3 \\
5\end{array}$ & $\begin{array}{l}2 \\
0\end{array}$ & $\begin{array}{l}1 \\
1 \\
5\end{array}$ & 8 & 8 & $\begin{array}{l}8 \\
2\end{array}$ & $\begin{array}{l}7 \\
2\end{array}$ & 0 & 5 & 2 & 8 & 3 & & & $\begin{array}{l}2 \\
1\end{array}$ & $\begin{array}{l}1 \\
9\end{array}$ & $\begin{array}{l}1 \\
6 \\
\cdot \\
5\end{array}$ & $\begin{array}{l}1 \\
2 \\
. \\
5\end{array}$ & - & 22 \\
\hline $\begin{array}{l}\text { Nematode } \\
\text { 200C Inocu- } \\
\text { lated }\end{array}$ & 24 & $\begin{array}{l}2 \\
8 \\
0\end{array}$ & $\begin{array}{l}2 \\
4\end{array}$ & $\begin{array}{l}2 \\
2 \\
0\end{array}$ & $\begin{array}{l}1 \\
9 \\
7\end{array}$ & $\begin{array}{l}1 \\
7 \\
5\end{array}$ & 5 & 5 & 0 & $\begin{array}{l}1 \\
1 \\
5\end{array}$ & 5 & 0 & 5 & 7 & 2 & 2 & 5 & 7 & 2 & & & $\begin{array}{l}2 \\
3\end{array}$ & $\begin{array}{l}2 \\
0\end{array}$ & $\begin{array}{l}1 \\
7\end{array}$ & $\begin{array}{l}1 \\
5\end{array}$ & $\begin{array}{l}1 \\
2\end{array}$ & 19 \\
\hline $\begin{array}{c}\text { Nematode } \\
\text { Proteins (NP) }\end{array}$ & 18 & $\begin{array}{l}2 \\
8 \\
0\end{array}$ & $\begin{array}{l}2 \\
6\end{array}$ & $\begin{array}{l}2 \\
5 \\
0\end{array}$ & $\begin{array}{l}2 \\
0 \\
0\end{array}$ & $\begin{array}{l}1 \\
9 \\
0\end{array}$ & 6 & 5 & 3 & $\begin{array}{l}8 \\
5\end{array}$ & 5 & 0 & 8 & 7 & 3 & 2 & 8 & 5 & 2 & ( & & - & - & - & - & & 16 \\
\hline
\end{tabular}

' - ' indicate no band and 'nematode protein' not included in the treatments group.

\subsection{On Genetic Effects of OR, OGR, and NF-Proteins}

Table 2 and Figure 2; shows the genetic effects on molecular weight $(\mathrm{kD})$ of okra root $(\mathrm{OR})$, and okra gall root (OGR) proteins for all pretreatments effects of both the ultra-highdiluted biomedicines; Gall 200C, and Nematode 200C on M. incognita pathogens causing RK-disease of the okra plants respectively. An analysis of root proteins of all 4-groups and nematodes female's (NF) proteins by electrophoresis and densitometer scanning of all the test OR and OGR-proteins show that both the ultra-high-diluted biomedicines; Gall 200C, and Nematode 200C -pretreatments resulted in an increased number of proteins in the roots than uninoculated untreated and inoculated untreated groups; the highest number of root proteins in the ultra-high-diluted biomedicines Nematode 200C and Gall 200Cpretreated inoculated group is 24 and 23 respectively, and next highest number of the root protein is 18 in the NF-protein, and 15 in the inoculated untreated group and the lowest number of protein is 11 in the uninoculated untreated group respectively (Table 2 and Figure 2). The highest molecular weight of the OR-protein-gene is $295 \mathrm{kD}$ and the lowest molecular weight of the OR-protein genes is $11 \mathrm{kD}$. The lowest number of the new pathogenesis-related protein genes (PR-proteins) is 4 in the uninoculated untreated okra roots, and the highest number of the new PR-proteins-genes is 22 in the ultra-high-diluted 
biomedicines Gall 200C -pretreated okra -pretreatment-group, 19 PR-proteins-genes in the Nematode 200C pretreated okra -pretreatment-group, 14 in the inoculated untreated group, and the lowest number is 4 PR-proteins-genes in uninoculated untreated treatment-group respectively, and the NF contained 18-proteins-genes and the molecular weight of the NF proteins-genes ranging from the lowest $12 \mathrm{kD}$ to the highest $280 \mathrm{kD}$, and the total number of the PR-proteins-genes of NF is 16 in comparison to the uninoculated untreated group (Table 2 and Figure 2).

\section{Discussion}

\subsection{On Growth}

The present study confirmed again that the okra plants (OP)-growth in terms of fresh biomass of shoot and fruits, and the number of fruits was higher than inoculated untreated groups in both the pretreatment groups of $\mathrm{OP}$ treated with the ultra-high diluted biomedicines; Gall 200C, and Nematode 200C, but reverse in the fresh biomass of roots of inoculated untreated one [15-20,40-44,71].

\subsection{On RK-Diseases}

Both the pretreatment groups of OPs treated with ultra-high-diluted biomedicines; Gall 200C, and Nematode 200C, decreased RK-diseases in terms of nematode infection, number of root galls, and nematode population of root in comparison to inoculated untreated groups, and the population of nematode in the soil was the maximum with both the group treated with Gall 200C, and Nematode 200C -biomedicines, and minimum with the inoculated untreated group, due to potential ultra-high-diluted effects of biomedicines, and it is also showed that the biomedicines; Gall 200C, and Nematode 200C, might induce synthesis of some antagonistic substance in the treated-OP, which is proved from the inoculated untreated okra root galls (ORG) contained the highest protein-content due to presence of a large number of nematodes [3-20,40-69,71].

\subsection{On Toxicity}

In the recent study is also confirmed that the high-diluted biomedicines; Gall 200C, and Nematode 200C, had no direct toxic effects on nematodes juveniles, and okra plants, but it induced synthesis of some resistance substances in okra plants to $M$. incognita infection for preventing RK-diseases in the OPs, and for these reasons, both the pretreated group had significantly greater fresh biomass of shoot-and fruits- plants than inoculated untreated one [15-20,40-44,71].

\subsection{On Defense Response}

The present experiment showed that both the high-diluted biomedicines; Gall 200C, and Nematode 200C, act as potential preventive biomedicines natural vaccines against plant diseases because of their defense resistance, and it's known that the lectins accumulated in galled regions of the OR- infected with the RK-disease [72]. It's already known that many crop plants will be induced by acquiring systemic resistance for the localized virus-infection or non-pathogenic, and pathogenic-microorganisms or their culture-filtrates or gas or salicylic-acid, etc. protects plants from the numerous pathogens attack, by working systemically [15-20,40-44,71-83].

\subsection{On PR-Proteins-Genes}

It is well known that the M. incognita is known to share common antigens with its host plants [84], and Iqbal et al. (2020) informed that the attempt to 'Silence Genes' of the root-knot nematode, $M$. incognita results in diverse responses including an increase and no change in expression of some genes [85]. So in both the pretreated-plant's roots show that the ultra-high-diluted biomedicines; Gall 200C, and Nematode 200C-pretreatments resulted in an increased number of proteins-genes in the root than uninoculated untreated and inoculated untreated-okra plants-groups, and the highest number of root proteins in 
the ultra-high-diluted biomedicines Nematode 200C and Gall 200C-pretreated inoculated group is 24 and 23 respectively, and next highest number of the root protein is 18 in the NF-protein, and 15 in the inoculated untreated group and the lowest number of protein is 11 in the uninoculated untreated group respectively, which also proved and confirmed that during infection with the nematode, host plants showed minimal defense responses to the nematode because of this antigenic similarity, and the different PR-proteins-genes of the okra root gall (ORG) proteins ranging from 295kD (the highest molecular weight protein) to $11 \mathrm{kD}$ (the lowest molecular weight protein) of the OR-protein. And both the ultra-high-diluted pretreated biomedicines; Gall 200C, and Nematode 200C-stimulate the synthesis of the number of different PR-proteins-antigens-genes that must induce defense responses in which the nematodes fail to survive or tolerate, and it is also proved from the plant-nematode interaction, newly synthesized PR-proteins genes have been found in potato plants infected with the potato-cyst-nematodes Globodera pallida and G. rostochiensis [86-89]. It is also reported that salicylic acid (SA) increases resistance in plants against RKdiseases by inducing expression and accumulation of pathogenesis-related-I protein $(14 \mathrm{kD}, \mathrm{PR}-\mathrm{I})$ in the sprayed plant-root and leaves, and it sprays enhances-PAL higher activity in infected-roots [15-20,40-44,71-89].

\subsection{On PR-Proteins-Genes of NF}

The 16 PR-proteins-genes out of total 18 proteins-genes of NF of $M$. incognita in comparison to the uninoculated untreated group, and the molecular weight of the nematodeproteins-genes ranging from $12 \mathrm{kD}$ to $280 \mathrm{kD}$, already confirmed the potential efficacy of the both ultra-high-diluted biomedicines-Gall 200C, and Nematode 200C, use as an effective stimulus for the expression of many new defense-related PR-proteins-genes might be provided resistance to nematode-infection in okra plants, and also due to nematodes present in the gall roots, and it can be preventing pathogenesis in patients with COVID-19 due to more or less proteins-genes range $(240 \mathrm{kD}$ to $26 \mathrm{kD})$ in different bovine- and humancoronavirus-structural-proteins which send genetic-information, and the SARS-CoV-2 genes may integrate with human-DNA to code the essential nonstructural-proteins like an RNA-polymerase also, and the nematode-proteins-genes slip into human-chromosomes and the diverse immunological-factors on viral-dissemination, immunotherapeutic-options, and inflammatory-responses, and need molecular-characterization and understanding of the human-coronavirus-life-cycle, structural and functional properties of SARS-CoV-2 spike-protein for potential antivirus-drug development, and analysis of therapeutic-targets for SARS-CoV-2 and discovery of potential-drugs by computational-methods, and genomic-characterization and epidemiology of 2019 or genomic-epidemiology has come of age during this pandemic affording to track SARS-CoV-2 sequences helped identify worrying-variants, with implications for virus-origins and receptor-binding also, for preventing the COVID-19, - but researchers are blind to emerging-mutations in someregions, and so it is thought, "the next pandemic by transforming food-systems for affordable healthy-diets" [15-20,40-44,71-93]. It is also proved from the cellular senescence (SnC) contributes to inflammation, multiple-chronic-diseases, and age-related dysfunction, and the $\mathrm{SnC}$ become hyper-inflammatory in response to pathogen associated molecular patterns (PAMPs), including SARS-CoV-2 Spike protein-1, increasing expression of viral entry proteins and reducing anti viral gene expression in non-SnCs through a paracrine mechanism [94].

\subsection{On Genetic Pretreatment Effects on ORGs PR-Proteins-Genes}

In both the ultra-high-diluted biomedicines; Gall 200C, and Nematode 200C-pretreated okra root galls (ORG), the 22 and 19 PR-proteins-genes out of total 23 and 24 proteins-genes respectively in comparison to the uninoculated untreated okra plant group, and the molecular weight of the ORGs-proteins-genes ranging from lowest $11 \mathrm{kD}$ to highest $295 \mathrm{kD}$, proved the potential efficacy of the pretreatment of the both ultra-high-diluted biomedicines; Gall 200C, and Nematode 200C- act as the potential effective stimulus for 
the expression of these 22 to 19 defense-related PR-proteins-genes which might be provided resistance to nematode-infection in okra plant. Both the ultra-high-diluted biomedicines; Gall 200C, and Nematode 200C-pretreatments collectively resulted in an increased number of PR-proteins-genes. And the genetic effects of both the ultra-high-diluted biomedicines; Gall 200C, and Nematode 200C-pretreatments resulted in an increased number of proteins-genes, are thought to induce systemic acquired resistance response of all the pretreated plants through the expression of pathogenesis-related (PR)-proteins-genes (22 to 19 numbers), which are more or less similar molecular range (295kD to $11 \mathrm{kD})$ of various coronavirus, and it will responsible for preventing RK and COVID-19 like virus diseases by inducing resistance of plants or increasing immunity of animals respectively, and enriched medical, pharmaceutical, science, technology, communication, agriculture, environment, health, socio-economy, issues [1,2,15-20,40-44,71,90-94]. And it is also noted that the ultra-high-diluted biomedicines Gall 200C will be the most potential preventive biomedicine vaccines due to its very close related genetic structure, emerging body of molecular evidences suggested a similar path to SARS and MERS viruses, and once they entered inside body, they overtake the cell's machinery, replicate, multiply and infect the adjoining cells, and all the viruses have a tell-tale signature on the surface known as antigens, identifying these antigens is what activate the immune system by producing the antibodies. And researchers have shown that a wide range of immune cells that react to SARSCoV-2 and helps in recovery could be helpful in the development of potential vaccines against 'Genome Variation' [1,2,95,96].

\subsection{Development of Future Drug or Vaccines Idea}

The different ultra-high-diluted biomedicines including Gall 200C, and Nematode 200C-pretreated okra root galls (ORG) protein could be induced the production of new defense-related PR-genes in the test plants and might be confirmed, and in near future, synthetic production of the particular RG-proteins-genes might be the most potential costeffective emergency personalized-biomedicine vaccines against coronavirus 2 like pandemic viral diseases by increasing immunity, and helping policy initiative clinical research in all areas in the field of advanced medical, pharmaceutical, science, technology, communication, agriculture, environment, health, socio-economy, agronomy, plant breeding, horticulture, aquatic sciences, and different issues by preventing plant diseases and COVID-19 like variants also. Thus, RG-proteins will serve as the most effective biomedicines vaccine that might be the potential cheapest, non-phytotoxic, non-pollutant, conserve our biodiversity, and this vaccine might be the most effective against the delta variant of coronavirus, and scholars that give good scope for new development and future research in various fields of pathology-medical-pharmacology preventing fungal and brain infections by increasing the post-COVID weakened lungs as well as the immune also [1,2,15-22,25,40-44,71,90-97]. And in the near future ultra-high-diluted biomedicines; Gall 200C, and Nematode 200C pretreatment gall GR or NF may be used as mixing vaccines to provoke potent immune responses for the real-world efficacy and rare side effects [98]. And also help for the future mitigation strategies, and Covid appropriate and risk behavior at slums different areas also [99].

\section{Conclusions}

The pretreatments with ultra-high-diluted-biomedicines 200C and Nematode 200C are highly effective against the plant diseases in all respect of growth and fruits-production. The Gall 200C is more effective than the Nematode 200C, by inducing systemic-acquired-defense-response of the plants through the expression of pathogenesis-related (PR)-proteins-genes (22-14 numbers), which are more or less similar-molecular-range (295kD-11kD) of many coronaviruses, which will be responsible for preventing-RK and COVID-19 like virus-diseases by inducing-defense-resistance or increasing innate-immunity respectively, and advanced in medical-science, technology, communication, 
agriculture, agronomy, plant breeding, horticulture, health, environment, socio-economy, and different application issues with the pollution-free globe, developing new preventive typical-biomedical vaccines or treatments methods or drug development and research

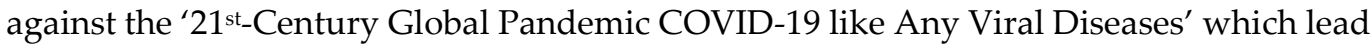
to optimal contributions to the field of policymaking drug and vaccine development. And the farmers and the world would be benefitted most; by collecting and uprooting gallroots after harvesting for cost-effective bio-controlling plant-diseases, and profit from shelling-and-buying of whole plants, fruits, and gall-roots also, and helps for the benefit of global health by developing the most cost-effective, personalized, non-toxic, easily preparable, easily maintainable, easily available and easily suppliable, vaccines or treatments methods from their own products.

\section{Patents}

It may be applied in the future for the patents from the work reported in this manuscript.

\section{Supplementary Materials: Nil.}

Author Contributions: The author himself has contributed all the work reported here.

Funding: This research received no external funding.

Data Availability Statement: Data is supplied by the corresponding author himself.

Acknowledgments: I am grateful to Ex-Prof. Dr. N. C. Sukul and Prof. Dr. S. P. Sinhababu, for necessary guidance and all facilities for the research work in the Department of Zoology, Visva-Bharati, Santiniketan - 731235, West Bengal, India. I am also thankful to Dr. Tapan Mondal for statistical analysis, and Mrs.Rupa Datta, Ex-Prof. Shelley Bhattacharya, and Dr. Partha Roy for biochemicalwork and densitometer-scanning of the same Department. I am also thankful to Prof. Dr. N. Banerjee and Dr. K. Ghosh, Department of Botany, Visva-Bharati, for needful bits of help. I express my deep gratitude to Mr. Rakesh Khan, Secretary, and Mr. Subhendu Bose, President with all Young-GreenMembers of the "International-NGO named Burdwan Green Haunter and Students' Goal" for arranging to many awareness programs on COVID-19. Last but not the least; I am thankful to the eminent-educationist-philosopher-social-worker Sri Tapaprakash Bhattacharya for inspiration and guidance.

Conflicts of Interest: The authors declare no conflict of interest. The funders had no role in the design of the study; in the collection, analyses, or interpretation of data; in the writing of the manuscript, or in the decision to publish the results.

\section{References}

[1] Müller NF, Wagner C, Frazar CD, Roychoudhury P, Lee J, Moncla LH. Viral genomes reveal patterns of the SARS-CoV-2 outbreak in Washington State. Sci. Transl. Med. 26 May 2021;13(eabf0202):1-12. doi:10.1126/scitranslmed.abf0202.

[2] Souilmi Y, Lauterbur ME, Tobler R. et al. An ancient viral epidemic involving host coronavirus interacting genes more than 20,000 years ago in East Asia. Cur. Biol. 2021;31:1-11.e1-e9. https://doi.org/10.1016/j.cub.2021.05.067.

[3] Datta SC. Weed-Plant Act as Vaccine against Plant-and-COVID-19 Diseases: Enriched-Agriculture-Health-Development SocioEconomy Sciences-Technology-Communication-Application. Int. J. Pharma. Sci. Clinic. Res. 2021a;1(1):1-17.

[4] Datta SC. Immediate apply cost-effective easily preparable-available $21^{\text {st }}$ century potential -ayurvedic-herbal-integrative-medicine-vaccine of COVID-19: achieved agriculture healthcare-socio-economy science technology communication mechanism! Int. J. Res.-Granthaalayah. 2021b;9(1): 227 - 247. https://doi.org/10.29121/granthaalayah.v9.i1.2021.2972.

[5] Datta SC. Only Environmental Science Act as Natural Bio-medicine Preventive Epidemic Model of 21st Century Pandemic Diseases. Editorial, Environ Sci. Ind. J. 2021c;17(1): e177. https://www.tsijournals.com/journals/archive/tses-volume-17-issue-1-year2021.html.

[6] Datta SC. Students Act as 21st Century Preventive-Pandemic-COVID-19 Model: Improved Advance-Clinical-Toxicology Biomedicine Green-Socio-Economy Science-Technology-Innovations. Adv. Cl. Toxicol. 2021d;6(1): 000204. doi: 10.23880/act16000204.

[7] Datta SC. Immediate apply cost-effective easily preparable-available $21^{\text {st }}$ century potential -ayurvedic-herbal-integrative-medicine-vaccine of COVID-19: achieved agriculture healthcare-socio-economy science technology communication mechanism! International Journal of Research-Granthaalayah. 2021e;9(1):227 - 247. https://doi.org/10.29121/granthaalayah.v9.i1.2021.2972. 
[8] Datta SC. High-Diluted Pharmacological-Potential Biomedicines Prevent 21st Century COVID-19 Like Pandemic: Improved Drugs-Research Biodiversity Agriculture Socio-Economy. Edit. Am. J. Phar. 2021f; 4(1):1031.

[9] Datta SC. Amaranth Plant Protects Climate-Health-Development Socio-Economy Sciences-Technology-Communication: Act as Potential Biomedicine-Vaccine against Plant and 21st Century-Epidemic COVID-19 Diseases. Exp. Opin. Env. Biol. 2021g;10:1.

[10] Datta SC. 21st-Century Preventive Non-Medicinal-COVID-19-Students-Model: Improved Med Life Clinics Sciences Technology Communication. Med. Life Clin. 2021h;3(1):1029.

[11] Datta SC. Dinna Nath Das-Middle English School and -Dispensary Act As a Model: The 21st-Century-Coronavirus-2 Resistance-Futuristic-Common-Ecofriendly-Complex-Green-Digital-School-Health-Ecosystem by Bio-Medicine-Vaccine-Nationalism-Equity-Passport. SunText Rev. Arts Social Sci. 2021i; 2(1):117-224. https://suntextreviews.org/doi/pdf/10.51737/27664600.2021 .017$.

[12] Datta SC. Sustainable Reopening of School Preventing Reinfection-Coronavirus 2 in New-Normal by Vaccine-NationalismEquity-Passport with Ginger-Drinks-Bio-Medicinal-Mid-Day-Meals! Int. J. Res.-Granthaalayah. 2021j;9(5):165-170. doi:10.7821/granthaalayah.v9.i5.2021.3936.

[13] Datta SC. Emergency Application of Ultra-High-Diluted-Biomedicines as Vaccine-Nationalism-Equity-Passport PreventingCoronavirus-2: Developed Medical Health Clinical Research Science Technology Communication! Medico Res. Chron. 2021k;8(2):132-135. https://doi.org/10.26838/MEDRECH.2020.8.3.497.

[14] Datta SC. Vaccine-Passport Bio-Medicinal-Meals Prevent Reinfection-Coronavirus-2: Improved Global-Health-Clinical-DrugDiscovery-Education-Research Socio-Economy-Science-Technology-Communication-Application! Aditum J. Cli. Biomed. Res. (20211; 2(3):1-7. http;//doi.org/04.2021/1.1022.

[15] Datta SC. Nematode Extract and Acaciasides Use as Preventive Biomedicines Against Plant Diseases: Improved Earth-Environ-

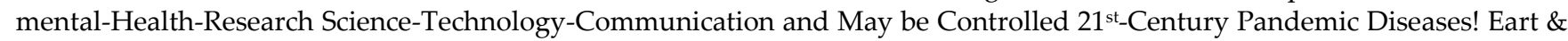
Envi Scie Res. Rev. 2021m;4:55-60.

[16] Datta SC. Animal-Biomedicine Controls Root-Knot-Disease in Lentil-Callus-Culture: Enriched Advanced-Clinical-Toxicology Socio-Economy Science-Technology-Communication by Preventing 21 st-Century-COVID-19-Like-Pandemic-Diseases. Adv. Cli. Toxicol. 2021n;6(2):000214.

[17] Datta SC. Biomedicines Suppress Root-knot Disease of Tomato and Coronavirus-Like-Pandemic-Diseases: Improved Agriculture Green-Socio-Economy Aquatic-Science-Technology-Communication!. J. Agric. Aqua. Sci. 20210;1:08-10.

[18] Datta SC. Genetic Basis of Nematode Extract May Be Preventive-Biomedicines Against Coronovirus-2 by Controlling RootKnot-Disease of Cowpea-Root-Callus: Enriched Agriculture Clinical Medical-Science-Technology-Communication! Glob. J. Cl. Med. C. Rep. 2021p;1(1):010-018.

[19] Datta SC. Genetic Effects of Ultra-High-Diluted-Biomedicines Gall 30C, Gall 200C, and Gall 1000C May Be a Vaccines Against Plant and COVID-19 Diseases: Improved Agriculture-Health-Medical-Pharmaceutical-Science-Technology-Communication-Issues! J. Dr. Res. Dev. 2021q;Peer Reviewing.

[20] Datta SC. Genetic effects of the biomedicines Gall MT (GMT) on advanced agronomy-plant-breeding-horticulture-environment socio-economy green-science-technology-communication-issues by preventing okra root-knot and COVID-19! Advances in Agronomy, Plant Breeding and Horticulture (Accepted); 2021r.

[21] Marshall M. COVID and the brain: researchers zero in on how damage occurs. Nat. 07 July 2021. https://doi.org/10.1038/d41586021-01693-6.

[22] Callaway E. The quest to find genes that drive severe COVID. Nat. Ne. 08 July 2021;595:346-348. https://doi.org/10.1038/d41586021-01827-w.

[23] Jones TC, Biele G, Mühlemann B, Veith T, Schneider J, Beheim-Schwarzbach J, et al. Estimating infectiousness throughout SARSCoV-2 infection course. Sci. 9 July 2021;373(eabi5273):1-13. doi: 10.1126/science.abi5273originally published online May $25,2021$.

[24] Cevik M, Bara SD. Networks of SARS-CoV-2 transmission. Sci. 9 JULY 2021;373 (6551): doi: 10.1126/science.abg0842.

[25] Sacco PL, Domenico MD. Public health challenges and opportunities after COVID-19. Bull W.H. O. 2021;99:529-535. doi: http://dx.doi.org/10.2471/BLT.20.267757.

[26] Yeha TY, Contrerasa GP. Viral transmission and evolution dynamics of SARS-CoV-2 in shipboard quarantine. Bull World Health Organ 2021;99:486-495. doi:http://dx.doi.org/10.2471/BLT.20.255752.

[27] Mallapaty S. Will COVID become a disease of the young? Nat. 08 July 2021.doi: https://doi.org/10.1038/d41586-021-01862-7.

[28] Workie E, Mackolil J, Nyika J, Ramadas S. Deciphering the impact of COVID-19 pandemic on food security, agriculture, and livelihoods: A review of the evidence from developing countries. Cu. Res. Environ. Sustain. 2020;2:100014. https://doi.org/10.1016/j.crsust.2020.100014.

[29] World Bank. Food Security and COVID-19. Last Updated: May07,2021. https://www.worldbank.org/en/topic/agriculture/brief/food-security-and-covid-19.

[30] Kochlar SI. Okra (lady finger) in tropical crops, a text book of economic botany. 1986;263-264.

[31] Chowdhury S, Kumar S. Okra Breeding: Recent Approaches and Constraints. Anna. Biol. 2019;35(1):55-60.

[32] Datta SC. Okra Maybe Potential Cost-Effective Personalized-Biomedicines Social-Vaccine against COVID-19: Improved Immunity Food-Security Green-Economy Science-and-Technology-Communication Applications. Innov. J. Med. Sci. 2020a;4(2): 520. http://ijms.co.in/index.php/ijms/article/view/101. 
[33] Gemede HF, Ratta N, Haki GD, Woldegiorgis AZ, Beyene F. Nutritional Quality and Health Benefits of Okra (Abelmoschus esculentus): A Rev. J. Food Pro. Technol. 2015;6:458. doi:10.4172/2157-7110.1000458.

[34] Sindhu RK, Puri V. Phytochemical, Nutritional and Pharmacological evidences for Abelmoschus esculentus (L.). J. Phytopharmacol. (2016;5(6):238-241.

[35] Anonymous. Indian Horticulture Database. National Horticulture Board, Ministry of Agriculture, Gov. India, Gurgaon, 2015.

[36] Chowdhury S, Kumar S. Okra Breeding: Recent Approaches and Constraints. Anna. Biol. 2019;35(1):55-60.

[37] Ledford H. First known gene transfer from plant to insect identified. Nat. Ne. 2021; 25 March. https://doi.org/10.1038/d41586021-00782-w.

[38] Damialis A, Gilles S, Sofiev M, Sofieva V, Kolek F, Bayr D. Higher airborne pollen concentrations correlated with increased SARS-CoV-2 infection rates, as evidenced from 31 countries across the globe. PNAS. 2021;118(12): e2019034118. https://doi.org/10.1073/pnas.2019034118.

[39] Datta SC, Mukherjee R. High-Diluted-Potential-Internal-Biomedicines Zingiber officinale Extract Prevent 21st-Century Pandemic: Enriched Drugs Health Socio-Economy! Unit. J. Inter. Med. 2021;V1(3):1-4.

[40] Datta SC, Datta R. Defence resistance of okra against root-knot disease by bio-nematicides. Pro. Zool. Soc., Cal. Univ., W.B., Ind. 2000;59(2):75-82.

[41] Datta SC, Sinhababu SP, Banerjee N, Ghosh K, Sukul NC. Meloidogyne incognita extract reduces M. incognita infestation of tomato. Ind. J. Nematol. 1998 a;28(1):1-5.

[42] Datta SC, Datta R., Sinhababu SP, Sukul NC. Acaciasides and root-knot nematode extract suppress Meloidogyne incognita infection in lady's finger plants. Proceeding of National Seminar on Environmental Biology, Visva-Bharati, Santiniketan, West Bengal, India, April 03-05, 1998, (Ed.) by Aditya,A.K. \& Haidar, 1998 b;205-209.

[43] Datta SC, Sinhababu SP, Sukul NC. Improved growth of silkworms from effective treatment of mulberry diseases by Accacia auriculiformis extract. Sericol. 1997;37(4):707-712.

[44] Datta SC. Bio-nematicides in the control of root-knot nematode. Ph.D. thesis, Department of Zoology, VisvaBharati, Santiniketan-731235, West Bengal, India, 1999.

[45] Datta SC.Effects of Cina on root-knot disease of mulberry. Homeopath. 2006a;95:98-102.

[46] Datta SC.Enriched Sericulture from Effective Treatment of Mulberry Diseases by Homeopathic Medicines. Adv. Biochem. Biotechnol. 2019a;7: 084. Available from: doi:10.29011/2574-7258.000084.

[47] Datta SC.Possible use of amaranth as catch crop for root-knot nematodes intercropped with okra. Phytomorphol. 2006b;56:113116.

[48] Datta SC. Improved Environment by Identification of More Susceptible Plant Between Cowpea and Mulberry for Root-Knot Disease. Op. Acc. J. Environ. Soil Sci. 2019b;2(5):242-245. doi: 10.32474/OAJESS.2019.02.000148.

[49] Datta SC. Enriched School Health For The Effective Healthcare Bio-Activity of Barn Owls. Res. Rev. Heal. Car. Op. Acc. J. 2019c;3(3):269-275. doi:10.32474.RRHOAJ.2019.03.000164.

[50] Datta SC.Enriched School Environment for the Effective Bio-Activity of Barn Owls. Int. j. Hor. Agric. Food scie. 2019d;3(3):119126. https://dx.doi.org/10.22161/ijhaf.3.3.2.

[51] Datta SC.Enriched Science and Technology Communication Economy in Agriculture by Use of Acacia sides as Potential BioAgents against Various Pathogens.Adv. Agric. Hort. Entomol. 2020b;2:1-13.

[52] Datta SC. Acacia auriculiformis-Extract Synthesis PR-Proteins Developed Potential Biomedicines-Vaccine against Okra-Diseases and COVID-19: Improved Science Technology Communications Bio-Economy Applications. Int. J. Res.-GRANTHAALAYAH, 2020c;8(10):249-270. https://doi.org/10.29121/granthaalayah.v8.i10.2020.1893.

[53] Datta SC. Cina-Pretreatments Act as Potential-Biomedicine-Vaccine against COVID-19 and Okra-Plant-Diseases: Synthesis PRProteins Increased-Immunity Improved Biomedicines-Economy Applications Science-Technology-Communications. Int. J. Ayur. 2020d;5(12):05-26. http://kibanresearchpublications.com/IJA/index.php/IJA/issue/view/116.

[54] Datta SC. Okra Maybe Potential Cost-Effective Personalized-Biomedicines Social-Vaccine against COVID-19: Improved Immunity Food-Security Green-Economy Science-and-Technology-Communication Applications. Innovat. J. Med. Sci. 2020e;4(2):5-20. http://ijms.co.in/index.php/ijms/article/view/101.

[55] Datta SC.Intercropped Cowpea Maybe Use as Biomedicine Improved Immunity against COVID-19: Enriching Science and Technology Communication Applications Food Security Economy. Diag. Therap. Comple. Tr. Med. 2020f;2020(1):35-48. doi:10.33513/DTCT/2001-07.

[56] Datta SC. Weeds-Vegetables and Fruits Act as Potential Biomedicines against COVID-19: Enriched Agriculture Biodiversity Socio-Economy Science Technology Communications by Controlling Plants Diseases. J. Exp. Biol. Agric. Sci. 2020g;8(Spl-1SARS-CoV-2): S139-S157. Available from: doi:10.18006/2020.8(Spl-1-SARS-CoV-2).S139.S157.

[57] Datta SC. Biomedicines-Aakashmini Cost-Effective COVID-19 vaccine: Reduced Plant-Diseases Enriched Science Technology Communications Socio-Economy Bio-Applications. Global J. Biosci. Biotechnol. 2020h;9(4):127-144.

[58] Datta SC. Discovery of COVID-19 Vaccine by Using Acaciades as a Phytomedicine Improving Science and Technology Communication Applications- An Ideas. Open Acc. J. Biogeneric Sci. Res. 2020i;2(1):1-30. doi:10.46718/JBGSR.2020.01.000032.

[59] Datta SC. Improved Science and Technology Communications: Barn Owl Act As Social Vaccine Against COVID-19. Int. J. Lat. Res. Sci. Technol. 2020j;9(3):6-13. https://www.mnkjournals.com/journal/ijlrst/Article.php?paper_id=10994. 
[60] Datta SC. Potential Policy-Developed Global-COVID-19-Vaccine: Enriched Medical Sciences and Technology Green-SocioEconomy. Cross Cur. Int. J. Med. Biosci. 2020k;2(10):143-154. doi:10.36344/ccijmb.2020.v02i10.001.

[61] Datta SC. Improved midday meal by using cowpea as eco-friendly crop controlling root-knot forming global, green, growth and green economy. Int. J. Adv. Res. 20201; Accepted.

[62] Datta SC. Biomedicines-Cina against COVID-19: Controlled Plant Diseases Enriched Science and Technology Communication Green Economy. The Int. J. Res. -GRANTHAALAYAH. 2020m;8(9):234-255. https://doi.org/10.29121/granthaalayah.v8.i9.2020.1537.

[63] Datta SC. NGO Act as Potential-Policy-Developer Social-Vaccine-COVID-19 Epidemic-Model until Discovery-of-Medical-Vaccine: Achieved Green-Socio-Economic Welfare Science Technology Innovations. Arch Commun. Med. Pub. Heal. 2020n;6(2): 225-232. https://dx.doi.org/10.17352/2455-5479.000111.

[64] Datta SC. Biological and BioSystems Engineering Barn Owl Controlled COVID-19: Engineering Bio-mechanical Biomedical Science Technology Communication Enriched Agriculture Environment. Int. J. Engineer. Sci. Inv. 2020o;Manuscript Id: IB910037, ISSN (Online): 2319 - 6734, ISSN (Print): 2319 - 6726 (Accepted).

[65] Datta SC. Artificial-Nest Rainwater-Harvesting with Fishery and Floating-or-Rooftop-Gardening Act as 21st Century CivilEngineering COVID-19 Epidemic-Model: Improved Biodiversity Agriculture Socio-Economic Environmental-Sciences Technology-Communication. J. Civil Engine. Environ. Sci. 2020q; 6(2):022-036. https://dx.doi.org/10.17352/2455-488X.000037.

[66] Datta SC. Homeopathic Medicines Aakashmoni Will Be the Best Vaccine Against COVID-19: Enriching Agriculture Science and Technology Communication Mechanism Application Issues!” Int. J. Res. -GRANTHAALAYAH. 2020r;8(11): 333-361. https://doi.org/10.29121/granthaa layah.v8.i11.2020.2458.

[67] Jeong M. Delta plus variant of SARS-CoV-2: How does it compare with the delta variant? M.N.T. on July 6, 2021. https://www.who.int/en/activities/tracking-SARS-CoV-2-variants/.

[68] Lowry OH, Rosebrough NJ, Farr AL, Randall RJ. Protein measurement with Folin-phenol reagent. J. Biol. Chem. 1951;193: 265275.

[69] Chatterjee A, Sukul NC. Total protein of galled roots as an index of root-knot nematode infestation of lady finger plants. Phytopathol. 1981;71:372-274.

[70] Laemmli UK. Cleavage of structural protein during the assembly of the head of bacteriophage T4. Nat. 1970;227:680-685.

[71] Datta SC. Animal-Biomedicines Prevent Disease of Tomato and Coronavirus-Like-Pandemic-Diseases: Enriched Agriculture Socio-Economy Science-Technology-Communication-Issues! Merit Res. J. Micro. Biol. Sci. 2021s;9(3):1-4.

[72] Das S, Sukul NC, Mitra D, Sarkar H. Distribution of lectin in nematode infested and uninfested roots of Hibiscus esculentus. Nematol. Medit. 1989;17:123-125.

[73] Ross AF. Systemic acquired resistance induced by localized virus infection in plants. Virol. 1961;14:340-358.

[74] Descalzo RC, Rahe JE, Mauza B. Comparative efficacy of induced resistance for selected diseases of greenhouse cucumber. Can. J. Pl. Path. 1990;12:16-24.

[75] Kuc' J, Strobel NE. Induced resistance using pathogens and nonpathogens. In: Biological Control of plant Diseases, (Eds. E.C. Tjamos) Plenum Press, New York, 1992: 295-300.

[76] Merra MS, Shivanna MB, Kageyma K, Hyakumachi M. Plant growth promoting fungi from Zoysia grass rhizosphere as potential inducers of systemic resistance in cucumbers. Phytopathol. 1994;84:1399-1406.

[77] Kiessig DF, Malamy J. The salicylic acid signal in plants. Pl. Mol. Biol. 1994;26:1439-1458.

[78] Kiessig DF., Durner J, Noad R, Navarre DA, Wendehenne D, Kumar D, Zhou JM, Shah J, Zhang S, Kachroo P, Trifa Y, Pontier D, Lam E, Silva H. Nitric oxide and salicylic acid signaling in plant defense. Proc. Nat. Aca. Sci., USA. 2000; 97:8849-8855.

[79] Schneider M, Schweizer P, Meuwly P, Metraux JP. Systemic acquired resistance in plants. Int. J. Cytol. 1996;168:303-340.

[80] Mauch-Mani B, Metraux JP. Salicylic acid and systemic acquired resistance to pathogen attack. Ann. Bot. 1998;82:535-540.

[81] Nandi B, Sukul NC, Banerjee N, Sengupta S, Das P, Sinhababu SP. Salicylic acid enhances resistance in cowpea against Meloidogyne incognita. Phytopathol. Med. 2002;41:39-44.

[82] Nandi B, Kundu K, Banerjee N, Sinhababu SP. Salicylic acid-induced suppression of Meloidogyne incognita infestation of okra and cowpea. Nematol. 2003;5(5):747-752.

[83] Mukherjee A, Mondal P, Sinhababu SP. Nematode extract-induced resistance in tomato against Meloidogyne incognita. Indian J. Sci. Technol. 2020;13(14):1476-1479. https://doi.org/10.17485/IJST/v13i14.234.

[84] McClure, Michael A, Misaghi I, Night EJ. Shared antigens of parasitic nematodes and host plant. Nat. $1973 ; 244: 306$.

[85] Iqbal S, Fosu-Nyarko J, Jones MGK. Attempt to Silence Genes of the RNAi Pathways of the Root-Knot Nematode, Meloidogyne incognita Results in Diverse Responses Including Increase and No Change in Expression of Some Genes. Front. Pl. Sci. 2020;11(328):1-13. doi:10.3389/fpls.2020.00328.

[86] Hammond-Kosack KE, Atkinson HJ, Bowles, DJ. Systemic accumulation of novel proteins in the apoplast of the leaves of potato plants following root invasion by the cyst-nematode Globodera rostochiensis. Physiol. Mol. Pl. Pathol. 1989;35:495-506.

[87] Rahimi S, Perry RN, Wright DJ. Induction and detection of pathogenesis-related proteins in leaves and roots of potato plants infected with pathotypes of Globodera pallida. Fund. Appl. Nematol. 1993;16:549-556.

[88] Rahimi S, Perry RN, Wright DJ. Identification of pathogenesis-related proteins induced in leaves of potato plants infected with potato cyst nematodes, Globodera species. Physiol. Mol. Pl. Pathol. 1996;49:49-59. 
[89] Rabaan AA, Al-Ahmed SH, Garout MA, Al-Qaaneh AM, Sule AA, Tirupathi R., et al. Diverse Immunological Factors Influencing Pathogenesis in Patients with COVID-19: A Review on Viral Dissemination, Immunotherapeutic Options to Counter Cytokine Storm and Inflammatory Responses. Pathogen. 2021;10:565. https://doi.org/10.3390/pathogens10050565.

[90] Cohen J. For WHO leader, a 'feeling that we're failing'. Sci. 2021a;372(6549): 1376-1377. doi:10.1126/science.372.6549.1376.

[91] Cohen J. Do coronavirus genes slip into human chromosomes? Sci. 2021b; 372(6543):674-675. doi:10.1126/science.372.6543.674.

[92] Cohen J. Further evidence supports controversial claim that SARS-CoV-2 genes can integrate with human DNA. Sci. 2021c; Posted in: Heal. Corona. doi:10.1126/science.abj3287.

[93] Camell CD, Yousefzadeh MJ, Zhu V, Prata LGPL, Hug MA, et al. Senolytics reduce coronavirus-related mortality in old mice. Sci. 2021;eabe4832:1-20. doi:10.1126/science.abe4832.

[94] Martin YH. COVID-19: Which vaccines are effective against the delta variant? M. N. T. June 22, 2021.

[95] Hakmaoui A, Khan F, Liacini A, Kaur A, Berka Y, Machraoui S et al. Relevant SARS-CoV-2 Genome Variation through Six Months of Worldwide Monitoring. Hindawi BioMed. Res. Int. 2021;5553173:10. https://doi.org/10.1155/2021/5553173.

[96] Yousaf A, Hameed Y. COVID-19 and Human Immune Response: A Literature Based Review. Open J. Med. Sci. 2021;1:10-14. doi: 10.31586/ojms.2021.010103.

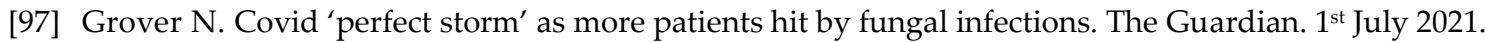

[98] Lewis D. Mix-and-match COVID vaccines: the case is growing, but questions remain. Nat.News, 01 July 2021. https://doi.org/10.1038/d41586-021-01805-2.

[99] Kar S., Mohapatra I., Mishra A., Banerjee A. Mitigation strategies and Covid appropriate and risk behavior : A descriptive study at slums of Bhubaneswar, Odisha. Adv. Res. J. Multidisc. Disco. 2021;57(1):01-06 . 